\title{
1, 2, 3, Action: Using Performance in Higher Education to Develop Teachers and Learners
}

\author{
Kelly Mancini Becker
}

\begin{abstract}
This paper explores the use of performance in a college-level course that teaches education majors how to use drama, dance, and music in their instruction. Students engage in drama activities such as improvisation and playbuilding in an effort to experience firsthand the benefits of such practices for their future classrooms. The essay shares some of the students' experiences in this course. A common outcome shared is that the processes encouraged students to get out of their comfort zone, which they found beneficial to their learning. The essay examines how having students perform may help them develop as both a learner and a future teacher.

It is the final exam day for my course, "Integrating the Arts Across the Curriculum," which is being taught at a midsize land grant university in the Northeastern United States. The course is geared towards teaching future elementary school teachers how to infuse the performing arts into their instruction of the general curriculum. The room is abuzz. There is a group of students in multicolored shirts-each color representing a healthy food group. One cluster of students is putting the finishing touches on their paper plate masks, while another group is practicing their song one more time before they perform their piece. This is the final project for the course where they perform a piece based on their arts-integrated unit which integrates drama, dance, and/or music with a content area like math, social studies, or literacy. One piece is a dance performance that shows the life cycle of plants. Another is a play about important women in history where each student performs a monologue that they have written about an influential woman. One performance is a staged fairy tale based on a Cajun version of Little Red Riding Hood set in Louisiana. This group's unit plan focused on how fairy tales were adapted and interpreted in various parts of the world. One particular performance in this piece stood out. The student who played the role of the alligator-what the Cajun version used as the villain instead of a wolf-took the stage with ease. He adorned a paper plate mask he had made with big alligator teeth and a mischievous grin (see Figure 1). When Little Red Riding Hood asked about his great big eyes, he responded with a big voice and a hint of a Cajun accent: "The better to see you with my dear!"

I call attention to this performance because the student who played this role demonstrated the most growth of any of the students that semester. At the start of the semester, he hardly spoke in class and was active but reticent in other performative activities. However, by semester's end, he amazed us all by taking on this major role. This student could have easily chosen a smaller part in this final performance, but he took on one of the most challenging-the villain-and a comic character at that. This transformation from reticent student to lead actor demonstrates what can be gained when alternative
\end{abstract}


modalities are engaged in the learning process. In his final reflection, he shared how far he had come in this course:

This was a lot of learning for me. I learned that I can go out of my comfort zone, and everything will be ok. Nothing bad happened when I challenged myself. The biggest challenge was getting over that battle in my head. Once I did that, it was easier.

Looking at how much I struggled, that will do a lot for me when I am teaching kids who are struggling in the same way I did. I am sympathetic for that, but at the same time, I know it can be overcome and that it is just something that you need to ease into and create a community first. I am beyond grateful for how much you pushed me in this class to just go for it, because if you just let me float by, I never would have grown like this, and now that it's over, I really am proud of how much further I have come. I really didn't see this coming, and I am excited to implement this into teaching. This kind of stuff really does work, and I am glad I got to see it first hand.

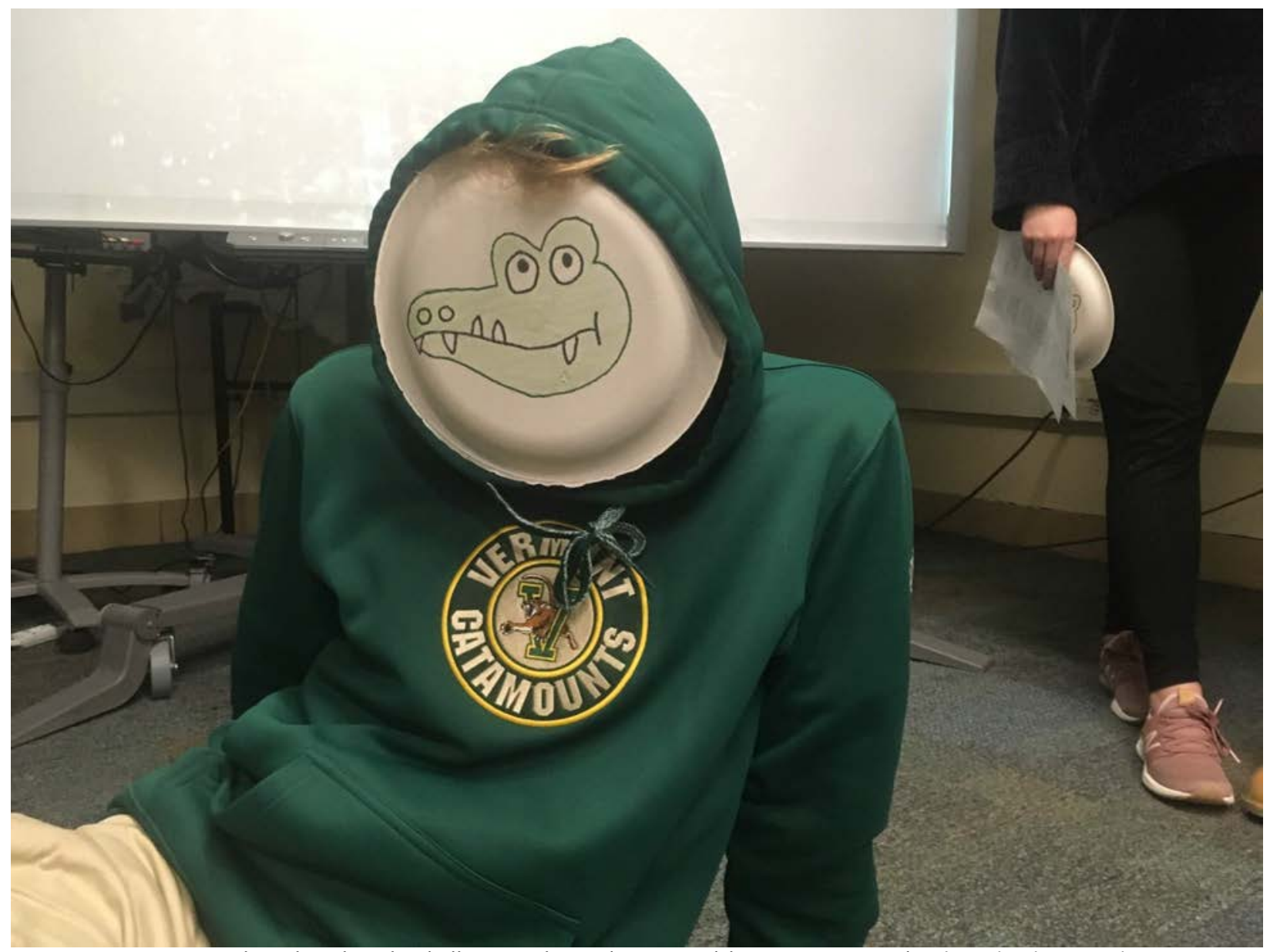

Fig. 1: Student plays the role of Alligator in his performance of the Cajun version of Little Red Riding Hood.

As this student shared in his reflection, the use of performance had a profound impact on his learning. He was pushed out of his comfort zone and challenged in a new way. He also built confidence in himself 
by overcoming some of his fears. This student also learned about how powerful performance can be for students in their learning process, which was something he experienced firsthand.

This final performance was an outcome of a course that integrated drama into classroom instruction. The use of drama in classroom instruction, what has been called "arts integration" or "learning through the arts," has been proven to benefit students in many ways (Burnaford, Brown, Doherty, \& McLaughlin, 2007; Bamford, 2009; Hardiman, Rinne, \& Yarmolinskaya, 2014). Elliot Eisner (2002), one of the leaders in the field, has argued that the arts are vital for students' cognitive development and thus need to be included in our teaching practices:

I argue that many of the most complex and subtle forms of thinking take place when students have an opportunity either to work meaningfully on the creation of images - whether visual, choreographic, musical, literary, or poetic - or to scrutinize them appreciatively. (p. xi)

Over the past two decades, research has supported this claim, touting the benefits of arts integration on students' academic and cognitive growth as well as their social skills (Burnaford et al., 2007; Bamford, 2009; Hardiman et al., 2014). Recent studies have shown that integrating drama into instruction can affect student engagement (Miller \& Bogatova, 2018) and academic achievement (Snyder, Klos, \& GreyHawkins, 2014). Hardiman (2003), in her Brain Targeted Teaching Model that utilizes research in neuro and cognitive sciences to improve teaching, shares that drama, music, and the visual arts activate the neurotransmitter serotonin which enhances cognitive skills and retention. Therefore, using varied modalities in the classroom positively influences student learning.

While the impact of the arts on learning is well documented in K-12 classrooms, there is sparse research on the impact of arts integration in higher education courses. One relevant study investigated the impact of using theater techniques and performance in the exploration of issues of race in a college class. The researchers found that the use of drama, dance, and performance enhanced and deepened learning and facilitated communication, and that the use of these modalities, which required students to "step out of the comfort zone," acted as a key aspect of the learning process (Sharma, Catalano, Seetzen, Minors, \& Collins-Mayo, 2019, p. 202).

\section{Performance and Vulnerability}

Getting students out of their comfort zone is one of the main aims of my course. Performing in front of one's peers and engaging in activities like drama and dance-processes that are not often included in regular classroom instruction—requires some risk-taking by the participant. Performing requires that you be seen and heard. You have to stand in front of your peers and be present in a more vulnerable way, maybe even act a bit silly. For the young man in my course, facing his fears and taking the risk of performing made a big difference in his learning and growth as a future teacher.

Learning requires similar "risks" and exposure. To be truly engaged in the learning process, students must raise their hand to ask or answer a question, which can feel intimidating or challenging for some students. Not only do they have to "take the floor" and have all the attention on them, but they might also expose 
some lack of knowledge or offer an incorrect answer. In essence, students have to make themselves vulnerable.

Brene Brown (2015), the leading researcher on shame and vulnerability, defines vulnerability as "uncertainty, risk, and emotional exposure" (p. 34). Brown asserts that our ability to be vulnerable is essential to how we live, love, work, and learn: "learning and creating are inherently vulnerable" (p. 186). To learn you have to ask questions, admit you don't know something, or challenge ideas. However, the fear of making mistakes can hamper learning (Kelley \& Kelley, 2013; Metcalfe, 2017). Interestingly though, research shows that "failure" or making mistakes can be beneficial in the learning process (Metcalfe, 2017) because when we face our fears and try something new, we build our confidence, which encourages us to take more risks in the future, thereby leading to ongoing growth.

How do we teach students to face their fears and take a risk in the classroom? Performance is one way to accomplish this as it provides a space to take the stage, to be seen and heard, and try new things. It functioned in that way for my student who took on the role of the alligator after a semester of easing his way onto stage.

The student who played the alligator in his final project also expressed that the experience of taking the stage and getting out of his comfort zone was going to benefit him as a future teacher. He suggested that because of this experience, he could better relate to students' experiences of struggle and perhaps better guide them through it. This arts integration course is geared towards preservice teachers. In the course, I model how the arts, such as drama, dance, and music, can be integrated with any content area. They have to sing, dance, and act and engage in the process of making art. This hands-on learning opportunity allows preservice teachers to experience firsthand how effective these instructional practices can be. It also, as I have discovered, is helping them develop some important skills that they need to be a good teacher, such as listening, vocal range, and quick thinking-all skills that are essential for participating in the performing arts.

\section{Teaching as Performative}

Improvisation is a performative artform that I utilize often in this course. One improvisation game that I use to teach the basics of improvisation is called: "I am a mustache." The game begins with one student taking the "stage" (an area we have designated as such in our classroom) and professing that they are something, such as a tree or a dog. They make a pose and say with a loud voice: "I am a tree." As other students hear the line, they may add to this tableaux by stepping forward and professing that they are something that connects to the original idea. For example, they might profess that they are an apple on the tree or a child sitting below its branches. When the idea is exhausted, a student will step forward to say: "I am a mustache," which signals that this round of the game is finished. In a particularly dynamic round recently, one student called out: "I am a dad," and another student stepped forward to profess: "I'm the Hawaiian shirt on dad." 
This vignette demonstrates a few of the benefits of using performance to train preservice teachers. Many a veteran teacher will tell you that teaching is an "act," or that to keep students' attention you need to be an actor and perform. Liew (2013) explored the notion of teaching as performative:

Emerging center stage is the teacher-artist performing in a classroom theater before a live audience of students. Like the theater actor, the teacher-as-performer assumes a stage persona, asserts stage presence, and communicates through verbal and nonverbal actions to engageeven educate-the hearts and minds of student-audiences. (p. 262)

But where do preservice teachers learn this skill?

Some research has shown that using the performing arts, such as drama, can be an effective instructional strategy for training teachers. Toivanen, Komulainena, and Ruismäki (2011) argue that good teaching requires confidence, creative passion, and rich interactions, all of which can be taught through dramatic means such as improvisation, role-play, and movement activities. Their research showed that drama was an optimal tool for training preservice teachers. Spielman (2007) demonstrated the effect of performing skits to prepare preservice teachers to teach math. Arslan (2015) studied the use of creative drama in preservice teacher training and its effect on problem solving. While she did not find a statistically significant relationship between engaging in creative drama and problem solving, she argued that this was in part due to the limited exposure of preservice teachers to creative drama. Arslan does however argue that methods inherent in creative drama follow a similar process to problem solving and thus provide a space to practice them. She therefore touts the benefits of using creative drama in teacher training and suggests more studies to investigate its impact.

Norris (2009) also demonstrated that theater could be a "powerful education tool," especially in training student teachers (p. 65). In his creation of the Mirror Theater, he engaged in theater techniques with college students and student teachers in an effort to explore issues of teaching. He used improvisation to create the plays as he believed that improvisation could be useful to "articulate their underlying beliefs through concrete representations" (p. 45). Norris created many pieces with students studying to be teachers about the fears and concerns regarding student teaching such as: "Teaching is Like an Old Sneaker" and "Post Practicum Depression" (p. 69). This process of collectively creating plays was proven to be a helpful process for preservice teachers as it encouraged meaningful discussions about teaching and the teaching process.

I have found that the use of performance, especially improvisation, has been particularly effective for developing preservice teachers' voice (volume and expression), listening skills, and quick thinking and problem solving. First and foremost, performance helps students develop their teacher voice. Encouraging students to perform regularly for their peers requires a "loud enough to be heard voice" because the act of performing requires this skill to be embodied. Not only does one need to be heard in the back of the house, but an actor on stage also depends on hearing the line prior to cue their next line. Using a variety of games like "I am a mustache" also encourages the development of an expressive voice. Dramatic play often includes a wide variety of roles to be played that requires students to explore their range, volume, 
and expression. Performing in front of their peers and getting immediate feedback from an audience, fuels more rapid development in this area.

Because there is no set script for improvisation, the actors on stage need to develop some key skills to make it work; skills that are also vital for effective teachers such as listening, problem solving, and quick thinking. In a recent class, we played an improvisation game called, "one chair improv." In this game, one student is seated in a chair and knows nothing about who they are, where they are, or what is about to happen. The student who enters the stage has made these decisions and enters the stage to begin a scene. It is up to the seated player to figure out the who, where, and what quickly, so that they can play along. In a recent iteration of this game in my class, a student entered the stage and asked the person seated where they had been on October 15, 2006 and why their DNA was all over the crime scene. The seated player had to quickly make up a story about why there was no way they were anywhere near the scene of the crime.

This game, like most improvisation games, requires students to listen effectively. You have to build on what the person says prior to you and align with the reality they have established. If you start planning ahead, thinking about what you are going to say next, you are lost. Once your partner says a line, you have to immediately respond, which takes some quick processing and thinking. Sound like teaching? Engaging in improvisation is an excellent training platform for teachers who have to think on their feet all day and respond to whatever students throw at them. Doing improvisation can be scary. It is clear in this students' final reflection that going on stage and performing in front of their peers was very intimidating:

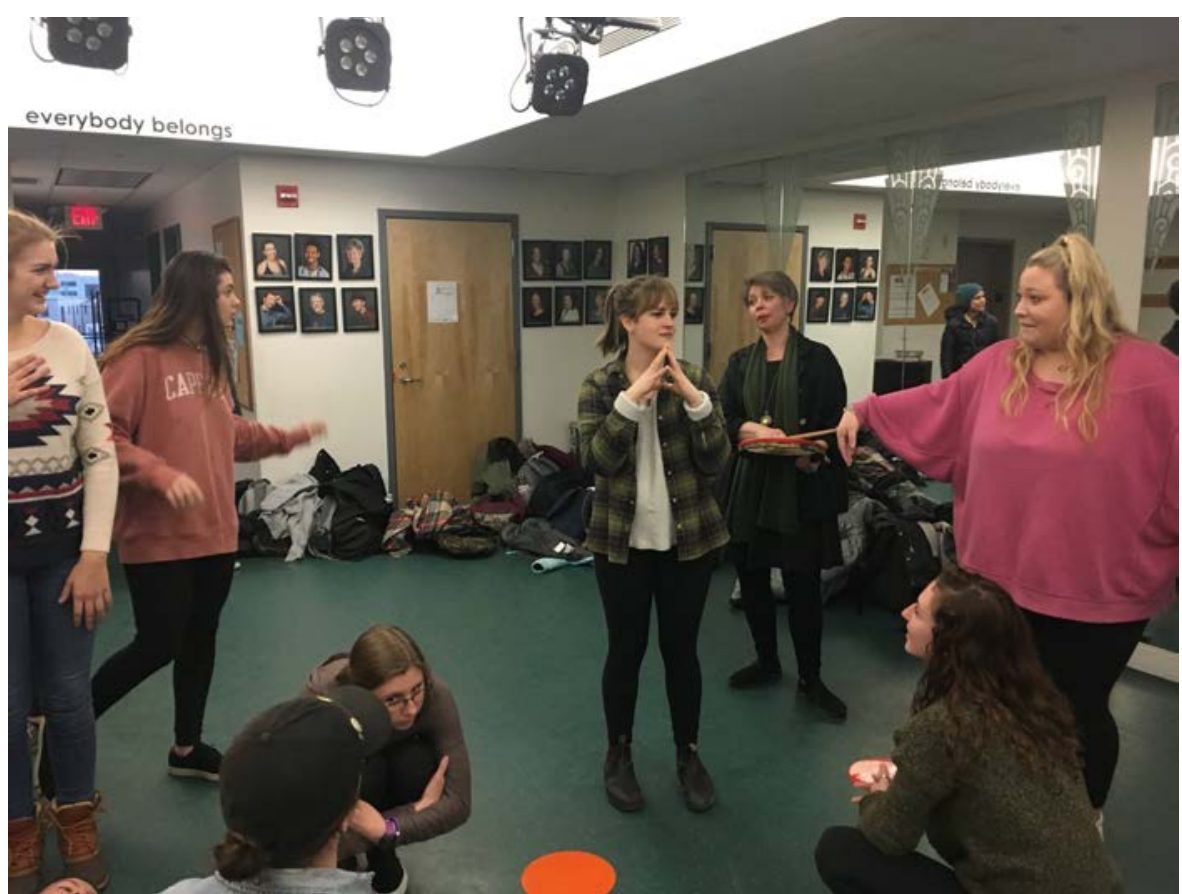

Fig. 2: Students partake in a workshop led by teaching artist Suzanna Olson at The Flynn Center for the Performing Arts, using their bodies to re-create the setting for a folk tale. 
At the beginning of this course, I had a really hard time participating and being outgoing in class. I am usually someone who has a pretty hard time articulating my thoughts to a large group of people because public speaking makes me pretty anxious. This can be even harder for me when it involves having to be creative and think on my feet. I remember the first time we did improvisation, I thought it would be impossible for me to ever step up and participate.... while it was hard for me to let go, and put myself out there, I did try to be more outgoing in my group. This was the first step in coming into myself as an artist. After that, I found myself slowly becoming more outgoing and participating more in class....through this class, at least now I know that if I work on it, and push myself out of my comfort zone, my anxiety surrounding speaking will be more manageable. Overall the biggest thing I learned from this class is to be more confident in my ability to speak in front of a large group of people. I was able to say what I felt, or perform without thinking about what everyone was thinking about me the entire time.

The act of performing helps to develop many skills in preservice teachers such as their teacher voice, ability to think on their feet, and listen effectively. It also provides a varied way to access and share learning, which may help improve the learning outcomes for college students.

\section{Active Learning and Drama}

K-12 educators work to differentiate instruction to find a variety of means to help students access learning. Active learning is a documented best practice (Hardiman, 2003). Research suggests that adding movement into instruction helps with retention and engagement, both key to learning (Hardiman, 2003). This is why I am teaching my preservice elementary education majors how to use such practices in their future classrooms. And while the benefits of such pedagogy are also improving the learning outcomes for my college-age students, it rarely finds its way into higher education. Fink (2013) argues that "information dump" is still the predominant teaching style in higher education classrooms that rarely include opportunities for problem solving, thinking, and decision making, which are all skills vital to post-college success in life and the workforce. Roberts (2019) argues that lectures still dominate in higher education despite our changing understanding of how college-age students learn:

[Lecture style classes] stubbornly persists, despite a range of challenges. Such challenges include concerns that too many student learning needs are submerged to one pedagogy, that 2-hour lectures cannot match changing attention spans and that the idea of knowledge being imprinted onto passive minds in a dimly-lit room on a campus for 2 hours at a time is at odds with the kind of conditions needed to engage better student learning. (p. 63)

Nathan and Sloan (2005) make a strong argument for the need for alternative methods for educating college students. Their report suggests that due to the changing demographics of those who now attend college, we need to change how and what we teach in higher education. Students are not only coming in with a wider range of skills, but we need to educate students for future careers that are vastly different from that of years past that require skills such as creativity and collaboration. Sloan and Nathan (2005), in their study of the Boston Arts Academy, argue that this can be accomplished effectively using the arts.

The benefits of active learning in higher education became apparent in a recent class session on the use of drama to teach westward expansion. In this class, I took students through a process called playbuilding (Tarlington, 1995) to create a play about life on the Oregon Trail. This was meant to demonstrate to 
preservice teachers how to use drama, music, and dance to create a play based on a specific content area to more fully engage their future students in the learning process. Not only is it a way to process what students are learning, which requires them to pull out the most important ideas in a reading, but it also provides a purposefulness to the work, as the goal is to create a play to share and teach others. To accomplish this task, students were put into groups, given specific readings focused on a particular aspect of westward expansion, and asked to develop a scene that shared the most salient information. As each of the groups performed, I was struck by what I noticed in my students. Many of the students who had hardly spoken up in class were all of a sudden acting, speaking, and fully active. It reminded me that no matter the age, students all have different skills and talents. The more we vary our instruction, the better it is for our students and for us as we learn more about how our students learn. In my student's reflection, it is clear that this experience made an impression on her:

Wait for the wagon, wait for the wagon! That was the main verse of our first musical number in the westward expansion show we were making. Hoola hoops covered with a sheet were carried around to create a wagon, and the cute little wagon representation wove around and around the little room (see Figure 3). After the song, there were some one-liners, a few skits, and then a square dance. Interestingly, all of these pieces of the show had been produced through (what could be) a complete social studies lessons. My favorite was the one in which students read about various aspects of wagon life and then worked in groups to create scenes depicting what they had learned. My group had made a scene that demonstrated what items a family moving west via wagon might have packed back during expansion. I don't think I'Il ever forget that barrels of water, lots of bacon, and various tools were among some of the key items to bring!

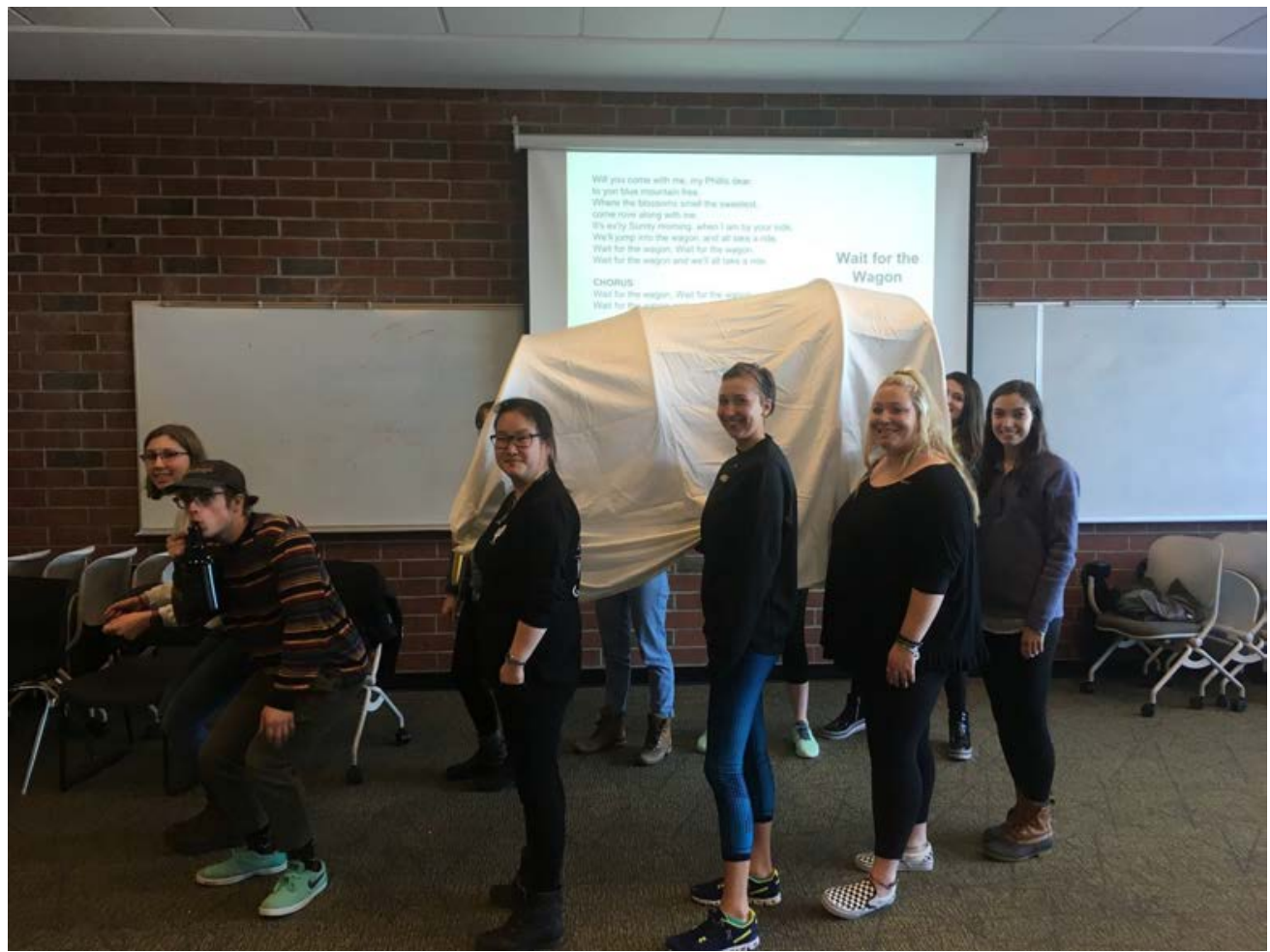

Fig. 3: Students use hula hoops and a sheet to re-create a covered wagon, while they perform a scene from the Pioneer Musical they create. 
This student recounts so many positive outcomes of this arts-integrated lesson where music, drama, and active learning were used to engage with social studies content. She asserts that she will "never forget" the act of packing the wagon which they acted out in their skits. Retention is one benefit noted in artsintegrated learning (Hardiman, 2003). This lesson also required students to use critical thinking skills. They had to read firsthand accounts of some of the issues that pioneers had to face as they headed west, pull out the salient ideas, and decide on the most important information to share in their performance. Eisner (2002) argues that engaging in arts learning requires the use of critical thinking and Fink (2013) suggests that skill building in these areas are nascent in most higher education instruction. Students also had to find a way to take those main ideas and physicalize them. Performance, for Butler-Kisber (2010), is an "embodied, narrative way of understanding the third dimension" (p. 136) and a valuable tool for inquiry and meaning making. Creating scenes based on academic readings required some creativity and imagination, but also collaborative skills, which are both much needed 21 st century skills. But what is most apparent from this account is enjoyment and engagement, which is a key ingredient in learning (Hardiman, 2003).

\title{
Stretched
}

The following is a one-word poem that was created on our last day of the course after students performed their pieces for their peers. The activity requires each student to share one word about how they are feeling. As this poem indicates, it is clear that students appreciated having performance as part of their learning experience. The word "stretched" resonates and to me is the main goal of any educational experience.

\section{Closing Circle: One-Word Poem}

\author{
Rejuvenated \\ Energized \\ Content \\ Hopeful \\ Engaged \\ Accomplished \\ Calm \\ Supported \\ Creative \\ Interested \\ Motorized \\ Connected \\ Excited \\ Inspired \\ Calm \\ Motivated \\ Excited \\ Jazzed up \\ Exhausted \\ Stretched \\ Determined
}


"1, 2, 3, action" is the chant I teach my students which we use to begin each performance. It signals that the actors on stage are ready and that the audience needs to prepare to be active observers. I have found that utilizing drama and performance in my teaching has been an effective way to engage my students in active learning no matter the age. It can be used as a tool to encourage students to process content by pulling out the most salient ideas, such as was done in playbuilding. It often allows for different students

to shine in my class, perhaps students who are not as vocal in whole group discussions. Performance is a way to differentiate instruction and offers a varied way to access and share learning. Using performance, such as improvisation, to develop skills for my preservice teachers, encourages the development of their teacher voice, problem solving, listening, and quick thinking. However, the greatest benefit of performance comes from the demands it places on students to go out of their comfort zone and take a risk in a safe and controlled environment. It is critical that more alternative teaching styles, like the use of performance, find their way into higher education teaching practices, and continued research on its impact on student learning is pursued.

\section{References}

Arslan, S. (2015). Pre-service teachers' level of problem solving and its relations with creative drama education. Education, 135(4), 423-433.

Bamford, A. (2009). The wow factor: Global research compendium on the impact of the arts in education (2nd ed.). Waxmann.

Brown, B. (2015). Daring greatly: How the courage to be vulnerable transforms the way we live, love, parent, and lead. Avery.

Burnaford, G., Brown, S., Doherty, J., \& McLaughlin, H. J. (2007). Arts integration frameworks, research and practice: A literature review. Arts Education Partnership.

Butler-Kisber, L. (2010). Qualitative inquiry: Thematic, narrative and arts-informed perspectives. Sage Publishing.

Eisner, E. (2002). The arts and the creation of mind. Yale University Press.

Fink, L.D. (2013). Creating significant learning experiences: An integrated approach to designing college courses. Jossey-Bass

Hardiman, M. (2003). Connecting brain research with effective teaching: The brain-targeted teaching model. The Rowan \& Littlefield Publishing Group, Inc.

Hardiman, M., Rinne, L., \& Yarmolinskaya, J. (2014). The effects of arts integration on long-term retention of academic content. International Mind, Brain, and Education, 8(3), 144-148.

Kelley, D., \& Kelly, T. (2013). Creative confidence: Unleashing the creative potential within us all. Crown Publishing Group.

Liew, W. M. (2013). Effects beyond effectiveness: Teaching as a performative act. Curriculum Inquiry, 43(2), 261-288. doi:10.1111/curi.12012 
Metcalfe. J. (2017). Learning from errors. Annual Review of Psychology, 68(1), 465-489. Retrieved from https://www.annualreviews.org/doi/10.1146/annurev-psych-010416-044022Py

Miller, J., \& Bogatova, T. (2018). Arts in education: The impact of the arts integration program and lessons learned. Journal for Learning Through the Arts, 14(1). doi:10.21977/D914128357

Norris, J. (2009). Playbuilding as qualitative research: A participatory arts-based approach. Routledge.

Roberts, D. (2019). Higher education lectures: From passive to active learning via imagery? Active Learning in Higher Education, 20(1), 63-77. doi:10.1177/1469787417731198

Sharma, S., Catalano, E., Seetzen, H., Minors, H.J., \& Collins-Mayo, S. (2019). Taking race live: Exploring experiences of race through interdisciplinary collaboration in higher education. London Review of Education, 17(2), Article 7. doi:10.18546/LRE.17.2.07.

Sloane, K., \& Nathan, L. (2005). Art transforms education: A Boston pilot school puts student learning center stage. The Journal of the New England Board of Higher Education, 20(1), 18-20.

Snyder, L, Klos, P., \& Grey-Hawkins, L. (2014). Transforming teaching through arts integration. Journal for Learning Through the Arts, 10(1). Retrieved from http://escholarship.org/uc/item/67d5s216

Spielman, L. (2007). A case in mathematics education using skits to connect preservice teachers' language and practices. Education, 128(1), 125-137.

Tarlington, C. (1995). Building plays: Simple playbuilding techniques that work. Heinemann Drama.

Toivanen, T., Komulainen, K., \& Ruismäki, H. (2011). Drama education and improvisation as a resource of teacher student's creativity. Procedia: Social and Behavioral Sciences, 12, 60-69. Retrieved from https://doi.org/10.1016/j.sbspro.2011.02.010

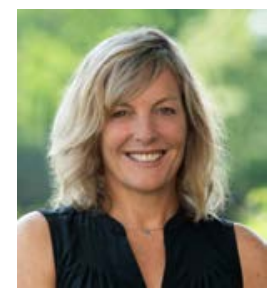

Kelly Mancini Becker has worked for two decades in the field of arts in education. She has been a teaching artist, educator, and arts administrator with such organizations as The Folger Shakespeare Library and The Shakespeare Theater in Washington, DC. Her specialty is the performing arts: drama, music, and dance with a focus on arts integration (or the use of the arts as a vehicle for learning). Kelly is currently a lecturer in the Elementary Education Department at The University of Vermont. Her research interests include arts integration, embodied cognition, arts-based research, and arts in peacebuilding. 
Kelly Mancini Becker

52 | LEARNing Landscapes | Spring 2020, Vol. 13 